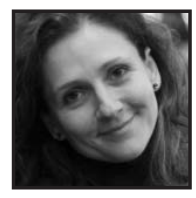

\title{
It's Like Telling People You Have Rats and Forgetting to Qualify Them as Pets: A Poet's Journey
}

\section{Daniela Elza}

\section{ABSTRACT}

How do I take my place as a learner, parent, educator in the fractal, multifaceted, kaleidoscopic process of being and becoming? How to negotiate the forces that pull us and push us in different directions? Or, how I discovered I am a poet, and survived to tell of it.

t all started with a four-line verse. Innocuous, while crossing a stretch of grass on the way home from the university. Instead of taking the asphalt path when I got off the bus, I walked through the grass. The same four lines every time, the same feeling as my high heels sank into the soft dirt. Almost tiptoeing through the exhale of summer. Between the busy bus street and the supermarket-this grassy interlude. Quite the unremarkable stretch, except for the soft breeze, the smell of evening grasses and trees, the welcomed end of the day. The moment came when I feared: if I forget the lines I lose the moment; this twilight space carving itself into words. So, I wrote it down. The year was 1989.

When I read Margaret Atwood's account a few years ago (in Negotiating With the Dead, 2002) the similarity was arresting. It happened to her while crossing a football field on the way home from school. It was not the poem, it was, as she put it, the electricity, "and after that writing was the only thing I wanted to do" (p. 14). 
In my excitement I showed the poem to my dad. It was titled: You Ask When?!:

When I feel the soft earth beneath my feet

and the summer flowers' scent caress me

when the breeze is caught and tangled in my hair

that's when I want you to be there.

Followed by two more stanzas of growing intimacy. My dad was sitting on my sister's bed, across from my desk. He read it. My room lit only by my desk lamp. My breath stilled. He looked up. There was a concerned look on his face. He asked: What made you write this? I deflated. I don't know what I was thinking.

For a long time after I would feel his discontent. This feeling that poetry was a waste of time. That poetry does not pay. It did pay, only, in a different way. It made me pay attention. An attention that put things together, made them make sense, made them whole. I could not explain that to my dad then.

Poetry is more than putting words on paper, or fitting them in a certain form. It is that electricity that becomes the conduit for a first translation between world and word. Robert Bringhurst (2008) reminds us it is a texture of thought. It is a way of being in the world, and it was here long before we were. He says: "The reason for writing poetry is that poetry knows more than any of us who write it. Poetry is what I start to hear when I concede the world's ability to manage and to understand itself" (p. 145). Annie Dillard (1989) also makes the connection between writing and knowing:

The writing has changed, in your hands, and in a twinkling, from an expression of your notions to an epistemological tool. The new place interests you because it is not clear. You attend, in your humility, you lay down the words carefully, watch all the angles. (p. 3)

This kind of inquiry is like looking for a needle in a haystack without knowing what a needle looks like.

Reading for exams was intense in those days. We did not study much during the semester. That was the student culture. I did most of my reading in the last few days before an exam. So, I was likely staying up the night before to read through all my notes. I had no time to mess around with poems. Still, at 2 a.m. the flowers in the vase stirred with presences. If I refused the poem, I did not make much progress with 
my reading. To fight it was wasting time. I would read and re-read the same paragraph without much luck. I realized when this feeling came (the arriving of a poem feeling) I had to listen. Even if it was just for efficiency's sake. What is more: I wanted to listen.

When I think of them now, they were not good poems, but they were my poems. They were first poems. In time I realized it is pointless to ignore a poem. It is futile to shut the door in the face of an emerging poem.

I don't know if one really chooses to be a writer. We choose to pursue it, to develop the discipline. Today, I can say I am a writer, but for the past twenty years I would have checked not sure if it was an option on a form. It was what I wanted, it also seemed unlikely, unserious, unreal. My parents thought this was no way to make a living. They are still right about that.

Over time, I noticed the look others gave me when I said I write. It is a bit like telling people you have rats, and forgetting to qualify them as pets. They give you that look, which seems to say: I am sorry. Perhaps, wondering if it's contagious, or if there is a cure. That writing was a way into questions, whose answers were beyond my grasp, escaped people. Few would light up and say: Rats make good pets. I had them once. Or: I have one or two myself. They are very smart. Mostly, it is that look. I do not know what poetry, or poets have done to deserve it. This silence that does not know what to do with itself. Or the silence will come after the question: Oh, have you published anything? And if I said: No. Well, there was that silence.

I remember the comment a teacher made once. Teacher had underlined the last line of my poem. It read: The Truth that are so many. Next to it, in red, was written: grammar. I thought that was my wow line. My little epiphany at that moment in my young life was considered a grammar mistake? I was so flustrated. (I thought I just made this word up for the occasion, but I see it is already on its way into existence.)

Even my knowledge of English was now suspect. Being between languages did not help. At times I was regarded as an ESL student, even though English is my academic language. I knew it was a grammar mistake. What was more exciting: it was a deliberate and a profound grammar mistake. I felt trapped.

Was I to forgive teacher? Feel sorry for teacher? Or feel sorry for myself? I was not strong enough then to feel sorry for my teacher. I was flustrated for not being seen, not being understood. Here again, the computer underlined the word (in red) the instant I hit the space bar. The instant I cut the umbilical cord, let the word loose 
into the world. Or did I let the world loose into my word? Such immediate feedback. I could have spent some time revelling in what, I thought, I had just created. Now I do not even need teacher to tell me this word is misspelled, that it might not even exist.

In 1993, while doing my Masters in Linguistics at Ohio University, I met the person who later became my husband. In the tentative months of getting to know each other he handed me Natalie Goldberg's Writing Down the Bones. I promised I would return it. It turned out I never had to. We got married.

Before Natalie's book, writing was sporadic, unpredictable. After reading it, writing became a discipline. It put the rite in writing. I could show up everyday, invite it. It took years to implement, to be precise, about ten. And a crisis moment to open space for redirecting, for change. Life happened in between. Anne Lamott (1995) observes:"To participate requires self-discipline and trust and courage, because this business of becoming conscious, of being a writer, is ultimately about asking yourself, as my friend Dale puts it, How alive am I willing to be?" (p. 236).

Staying with the writing every day for a few years also brought another revelation. That I was learning from my practice. As I was writing my poems, my poems were writing me. I found a mentor who helped me write more like me. Who, over the course of a few years, opened my eyes to what I was doing. It is hard to find such teachers who will let you, guide you toward being more you, and help you bring it out into your words.

In 2006, while doing my doctorate in Philosophy of Education, I was invited to publish a number of poems in a philosophy journal. I had been publishing in literary journals, but this was going to be the first peer-review of my poetry, my newly rediscovered voice. The journal did not have a tradition of publishing poetry. In fact, I later found out that my piece was the first one to appear in a section added to the journal called philosophical fragments. I submitted my poems knowing that is what I had to do. I was coming to the realization that poetry and philosophy are twin sisters separated at birth.

I sent the work to the editor. Then the thought hit me: I will be hearing back from two peers. I was petrified. Not because the work could get rejected-I was used to that by now. I feared the evaluation. What it could do to my voice, the joy in writing. I had not thought through those consequences. What could happen to that sheer delight of writing, which by now I had built into my day, my life, enjoyed its numerous rewards. 
Days dragged their feet across the beige carpet of my house. How to brace myself? I began to feel I should not have been so enthusiastic, so daring. Doubts flooded in. They don't need inviting. They sit there. Waiting. Moments when we were rejected, misunderstood, unacknowledged. They crouch on the periphery of this territory I have to jealously guard. A place I not only practice my craft, but, more importantly, my freedom. Could it go in a blink? Would it? The moment these doubts smell fear, they move in, take over. Could this be the end of a fragile experiment, this different way of walking along, of getting to know the shoreline of my mind and from there the world? The word line so misleading in describing the infinite complexity, the fractal kaleidoscopic nature of thought.

The review came back positive, even encouraging. Ok, these words are not adequate to convey what I felt. I printed it out. I carried it with me. At the slightest doubt that it was real, I re-read it. To myself, to others. Even while waiting at the crosswalk for the light to change. Especially that line that said:"...the author exemplifies the possibilities of poetry as a way to engage in philosophical discourse with skill, courage and heart" (Anonymous reviewer, written communication, October 2006).

That is what I hoped I was doing, and the only way at that point in my life I could do it. I could not write another academic paper. To be able to think on paper the way my mind thinks when it is full of questions and wonder, was very exciting. When big ideas buzz around my head and start taking their own unique-to-me-and-my-lifeand-my-image-world shape. Ruth Behar (2008) says: "You will reach a point, as I did, where there is no choice but to work from your poetic self" (p.67).I had reached that point.

Then there was the line that said, the poems were: carefully crafted, subtly sophisticated, inimitably imaginative, lyrically logical, and philosophically playful/purposeful (Anonymous reviewer, written communication, October 2006). The person, who had with such heart-felt enthusiasm responded to my work, is not only a peer in academia, but also a poet, a congenial soul.

The comments on the form were insightful. In my teen years I avoided form because it meant little to me. Now, I was witness to my form taking shape. I had a need for a more organic form, to pull the words away from each other for a number of reasons. The reviewer nailed a few of them.

As the day progressed I could almost recite the review: on the playground, while waiting for my kids, while cooking, on the phone with my sister, to my husband, 
over coffee with a friend. That night I could not go to sleep. If I closed my eyes I might wake up to find it never happened.

At 2 a.m. lines were still running through my head. Who else could I share this news with? Who else would understand? Without thinking I am boasting, overreacting, or un-humble? It had to be someone who knew what it takes-the work, dedication each day, how much editing, how many submissions, how much waiting.

A more pending question now was: who would be awake at this time of the night? It was day on the other side of the world. Of course, my parents. I snuck out of bed, went to the kitchen and dialed Sofia. A few windows still lit here and there in the high-rises. The co-op-dark. The ringing of the phone-unusually loud in the night. My voice could not be quiet enough. I read them the review. I read them the seven poems. I read them the review again.

I don't think my parents really believed in this whole poetry expedition. They kept hoping it was a phase. It has been the longest phase of all. The one thing that has stayed with me regardless of what country, school, job, language, or culture I was in. Looking back, poetry has always been there for me, even if I was not always there for poetry. When I was doing my degrees, writing academic papers on reading education, linguistics, semantics, pedagogy, or philosophy, poetry lay dormant. Except for the infrequent poem that gushed out. As if the mind has to be tuned in differently to invite poetry. Over-saturated with reading articles, textbooks, there was no room for anything else. All was defined by arguments, points, summary bullets. Institutionalized. It takes letting go, emptying, a certain kind of presence to allow poetry to flow through me. Egoless, I had to step out of myself as I knew myself. I had to be beside myself, to address something much larger. Robert Bringhurst (2008) says: "We are born questions. Culture is the thin but sometimes lovely web of answers we keep spinning for ourselves" (p. 50). I had to turn into a question, embrace wonder as my methodology. From there, listen to the world.

My parents regretted I abandoned my Ph.D. in Education when my daughter was born. It did not help when I kept sending them stacks of poems. Their presence in those years was a silence. I had completed all my coursework, had one more exam to sit for, and write a dissertation, when my first child was born. I thought hard: Baby? Dissertation? It is not that I had to choose one, or that one could not be without the other. But both would demand a big chunk, if not the whole, of me. If I dedicated myself to writing my dissertation, I was betraying my principles as a parent/teacher (that children come first). My daughter will never be one, or two, 
again. I could always go back to finish the degree. The situation was exacerbated by my visa status, which required me to be in school full-time to be legal in the States. This left its nightmarish marks on my life. A story to be told another time.

I dedicated those initial years (fully and completely) to my daughter, and later my son; to being the teacher and mother I have been writing about. No regrets. No one has taught me more about myself than my kids.I took my apprenticeship seriously. I came to see those first few years in a child's life as crucial. You give them that, you have given them a gift for life.I do not have to chase after them to do their homework. I do not have to tell them what to be interested in. I just need to guide and support them as they discover their voices, launch on their own journeys. All these thoughts unsaid between me and my parents. Yet, something shifted that night. I felt acceptance, even admiration. That is all I cared to feel. We have had enough stressful arguments on what makes one happy, what is important in life. Here it was the poems, the praising words of a reviewer.

By 3 a.m. I had committed enough to memory. I went to sleep thinking how not only were my first poetic steps in the academy met with acceptance, but I was also acknowledged by my own family. Soon after, my poems appeared in Paideusis. My parents have cheered me on since.

One has to write, to hope and trust, and it takes a lot of it.

The peer review was blind, but it opened my eyes. Had the review been condemning, however, where, how, and who would I be today? These concerns remain as I move toward the publication of my first full-length poetry book. These concerns remain for me as an educator. How everyday we can negate a care, a curiosity, a passion children come to school with. I am astonished at some of the stories coming home with my children of how petty teachers can get to feel they are in control.

The critic, the reviewer, is very much like a teacher, in that their words can effect transformation. I cannot personally thank this man or woman who took the time and the heart to review my work. But, there is always the story. If it gets written, there is a chance it will get read. These are a teacher's quiet and rare gifts. They are almost never immediate.

Today (with over 160 poems released into the world in over 50 publications, two books on the way) I am left wondering: How can this be? As if all my life I have been working toward this moment. In a world of growing uncertainty, how can we know what we are preparing ourselves for? Or our children? It is a most curious puzzle. 


\section{References}

Atwood, M. (2002). Negotiating with the dead: A writer on writing. Cambridge: Cambridge University Press.

Behar, R. (2008). Between poetry and anthropology: Searching for languages of home. In M. Cahnmann-Taylor \& R. Siegesmund (Eds.), Arts-based research in education: Foundations for practice (pp. 55-71). New York: Routledge.
Bringhurst, R. (2008). The tree of meaning: Language, mind and ecology. Berkeley, CA: Counterpoint.

Dillard, A. (1989). The writing life. New York: HarperCollins Publishers.

Lamott, A. (1995). Some instructions on writing and life. New York: Anchor Books.

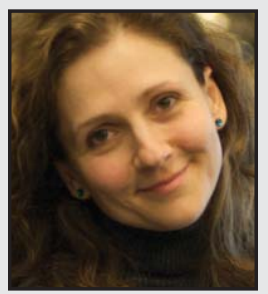

Daniela Elza just completed her doctoral thesis in Philosophy of Education (Simon Fraser University). Her interests lie in the gaps, rubs, and bridges between poetry, language, and philosophy. She dwells in the spaces that call us to attention, to an embodied awareness of the poetry that is our lives. In this process she not only finds that boundaries between philosophy and poetry blur, but writing also becomes a way of being, a vehicle for transforming consciousness, where we loosen our grip on the world to invite a more intimate connection with it. Daniela's work has appeared in over 50 literary and peer-reviewed publications.

LINKTO:

http://strangeplaces.livingcode.org/ 